\title{
Knowledge acquisition on communication with blind patients in nursing consultation
}

\author{
Aquisição de conhecimento para comunicação na consulta de enfermagem com o cego
}

Jaqueliny Rodrigues Soares ${ }^{1}$, Lorita Marlena Freitag Pagliuca², Eryjosy Marculino Guerreiro Barbosa ${ }^{3}$, Evanira Rodrigues Maia ${ }^{1}$

Objective: to evaluate the acquisition of knowledge of nurses in the nursing consultation on communication with blind patients. Methods: evaluation research, carried out by questionnaires applied before and after the experience of an educational program of an e-learning course. We used Contextual Lexical Analysis software for a Set of Text Segments for lexical analysis of the data. Results: 24 nurses participated in the pre-test and 11 in the test. Before the course, there was limited dominance in the thematic, especially in the non-verbal form. There was a predominance of the use of speech and writing in the nursing consultation. After the course, elements, we observe the apprehension of forms and functions of verbal communication; Improvment of non-verbal theories dominance; And their applications in the consultation with blind patients. Conclusion: the educational program allowed the nurses to acquire knowledge of verbal and non-verbal communication with blind patients in the nursing consultation in primary care.

Descriptors: Nursing; Health Communication; Visually Impaired Persons; Education, Distance; Knowledge.

Objetivo: avaliar a aquisição de conhecimento de enfermeiros na consulta de enfermagem sobre comunicação com o cego. Métodos: pesquisa avaliativa, realizada por questionários aplicados antes e após a vivência de um programa educacional na modalidade de curso a distância. Utilizou-se o software Análise Lexical Contextual de um Conjunto de Segmentos de Texto para análise lexical dos dados. Resultados: participaram 24 enfermeiros no pré-teste e 11 no pós-teste. Antes do curso, observou-se domínio limitado na temática, em especial da forma não verbal. Houve predomínio do uso da fala e da escrita na consulta de enfermagem. Após o curso, houve apreensão de elementos, formas e funções da comunicação verbal; melhoria do domínio das teorias não verbais; e suas aplicações na consulta com o cego. Conclusão: o programa educacional permitiu a aquisição de conhecimentos de enfermeiros para comunicação verbal e não verbal com o cego na consulta de enfermagem na Atenção Primária.

Descritores: Enfermagem; Comunicação em Saúde; Pessoas com Deficiência Visual; Educação a Distância; Conhecimento.

\footnotetext{
${ }^{1}$ Universidade Regional do Cariri. Crato, CE, Brazil.

${ }^{2}$ Universidade Federal do Ceará. Fortaleza, CE, Brazil.

${ }^{3}$ Universidade Estadual do Ceará. Fortaleza, CE, Brazil.

Corresponding author: Evanira Rodrigues Maia

Universidade Regional do Cariri/Departamento de Enfermagem. Av. Cel. Antônio Luiz, 1.161, Pimenta. CEP: 63105-000, Crato, CE, Brazil. E-mail: evaniramaia@bol.com.br
} 


\section{Introduction}

Thinking on the accessibility of people with disabilities is an urgent necessity. For the World Health Organization, there are over a billion people in the world with some form of disability. In the United States, ther is a prevalence of $12.0 \% ; 21.0 \%$ of these state that they are visual impaired ${ }^{(1)}$.

In Brazil, $23.9 \%$ of the population has some disability, the Northeast is the region with the largest occurrence $(26.6 \%)$. The state of Ceará holds a percentage beyond the national average (27.6\%). This data reinforces the findings of the World Health Organization, which demonstrate a strong link to the occurrence of disabilities with poverty. The disability with the highest incidence in Brazil (18.6\%) is visual impairment, followed by motor (7.0\%), hearing (5.1\%) and intellectual impairment $(1.4 \%)^{(2-3)}$.

Visual deficiency is considered an irreversible situation of visual response, due to congenital, hereditary and acquired causes, present in two forms: blindness, which is the total absence of vision, in which visual acuity is less than 0.05 in the best eye and low vision, which is the decrease in visual capacity and the perception of masses, colors and shapes ${ }^{(4)}$.

The World Report on Disability, a pioneer in the area of disability, indicates the greater tendency of this population to present health problems, low schooling and low economic level, because of the barriers of physical accessibility and communication, which prevent them to reach their potential and self care ${ }^{(5)}$.

Studies point out that blind people face significant barriers of communication with health professionals, among them nurses, who are unaware of communication techniques adapted to the needs of this population, what difficult assistance effectiveness $^{(2,6)}$. Observing this gap in their qualification, we proposed e-learning education techniques, since it gives the possibility of training professionals on a large scale, because there are no geographical and temporal boundaries.

The course Communication of the Nurse with the Blind Patient a 40 hours course distributed in four classes, directed to nurses of the Family Health Strategy, by means of the e-learning program. It approached models of communication to promote knowledge, values and deepen the reflection of communication accessibility as a tool for social inclusion of the blind person within the framework of the Unified Health System. By demonstrating the effectiveness of this technology it is possible to broaden the scope of nursing care for this public and to respond to the scientific community movement that is making research on web-based learning ${ }^{(7)}$.

The objective of this study was to evaluate the acquisition of nurses' knowledge in communication with the blind patients in nursing consultation.

\section{Methods}

Evaluation study that involved three Ceará universities and investigated the knowledge of the subjects before and after the application of an educational e-learning program. It is based on the pre and post-test evaluation model to measure learning ${ }^{(8)}$, performed in 2016, after dissemination using Whatsapp application, environment in which the subjects of the study were registered.

After registered on the Solar Platform, they had a face-to-face meeting with Primary Care nurses enrolled. In the inaugural class, we presented to the participants the e-learning environment, the schedule of activities, the objectives of the course and the forms of evaluation.

Data collection evaluated the knowledge of the participants in the before and after the course through the application of questionnaires they elaborated, with five open questions applied in person, in pre-test, and on-line, in the post test, that address the forms and functions of verbal and non-verbal communication, and the conduct of the Nursing consultation with the blind patient.

In the analytical and quantification phases of the data, we use the Contextual Lexical Analysis sof- 
tware for a Set of Text Segments (ALCESTE), version 4.0, which allows comparing the acquisition of knowledge before and after the educational activity. The program allows analyzing the semantic relationship between words and shapes.

In the corpus of analysis, each subject corresponded to an initial context unit (ICU), related to pre and post-test. The speeches of the participants are shown in the results to complement the sense of the classes. In the analysis, the program divided the ICU into elementary context units (ECU), with a smaller fragment of meaning. The ICUs numbered by the software were used to identify the subjects of the study.

The software used presents the steps of text reading and dictionary calculation; of the data arrays calculation and ECU classification, based on associative fields; description of the selected ECU and predominant vocabulary selection; and selection of ECU characteristics of each class, based on the correspondence factorial analysis (CFA), which consists of checking the interrelationships of the classes.

Through the statistical calculation of chi-squared, the software counted the vocabulary, the number of classes and the relationships between them. The lexical classes were characterized by their vocabulary and by the segments of texts that share that vocabulary. The study respected the demands on research involving human beings, through resolution 466/2012, and approved by the Ethics Committee on Research at the Universidade da Integração Internacional $d a$ Lusofonia Afro-Brasileira, under no 652,134, CAAE: 30183114.4.1001.5576.

\section{Results}

Of 124 possible participants in Primary Care of three municipalities, 24 participated in the pre-test and 11 in the post-test. The predominant were women (95.8\%) from 21 to 53 years old, (41.6\%) from 30 and 35 years old, a specialist (95.8\%), graduated between 1998 and 2012, in public institutions of higher education (75.0\%), acting in the Family Health Strategy
(39.1\%). Only two participants had prior experience in e-learning. Also only two participants had done a refresher 40 hours course in the area of disabled people, specifically LIBRAS. In table 1 , we can see the elements of the vocabulary in the pre and post-test.

Table 1 - Lexical analysis of the pre-test and post-test using Contextual Lexical Analysis software of a Set of Text Segments

\begin{tabular}{lcc}
\hline Elements of vocabulary & Pre-test & Post-test \\
\hline Participants & 24 & 11 \\
Total number of words in the text & 2,376 & 2,015 \\
Number of analyzable words & 1,787 & 1,984 \\
Socioeconomic variables & 6 & 6 \\
Textual units classified & 61 & 94 \\
Not analysable words & 589 & 31 \\
\hline
\end{tabular}

The vocabulary calculation of the pre and post-test corpus evidenced the acquisition of words of significant lexical weight after participating in the educational program. In the pre-test database, $61.0 \%$ of the corpus was used, while in the post-test there was progression to $94.0 \%$ of analysable forms considered by the software. The analyzed units brought by the group after the course had semantic value, and the number of words not analyzed by the software reduced after the course.

The lexical analysis generated two major themes: knowledge of nurses on communication with blind patients before e-learning course and knowledge of nurses on communication with blind patients after e-learning course. We subdivided both themes, in turn, into three discursive classes or categories.

Knowledge of nurses on communication with blind patients before e-learning course

Data processing was carried out by reference to the frequency of chi-square $\geq 4$ for evocations of a same inducer stimulus.

Figure 1 expresses the intersection of the vocabulary, considering the frequency of the words and the classes' incidence in the graphic plane, pointing, according to the location of these classes, the interaction between them. The E1 axis, in black, in the 
horizontal line, translates the strongest words or expressions evoked by the participants of the study, with $55.0 \%$ of variance, added the percentile of $45 \%$ relative to the E2 axis, in the vertical line of the graph. The highlighted words are the most relevant in the Chi-squared test.
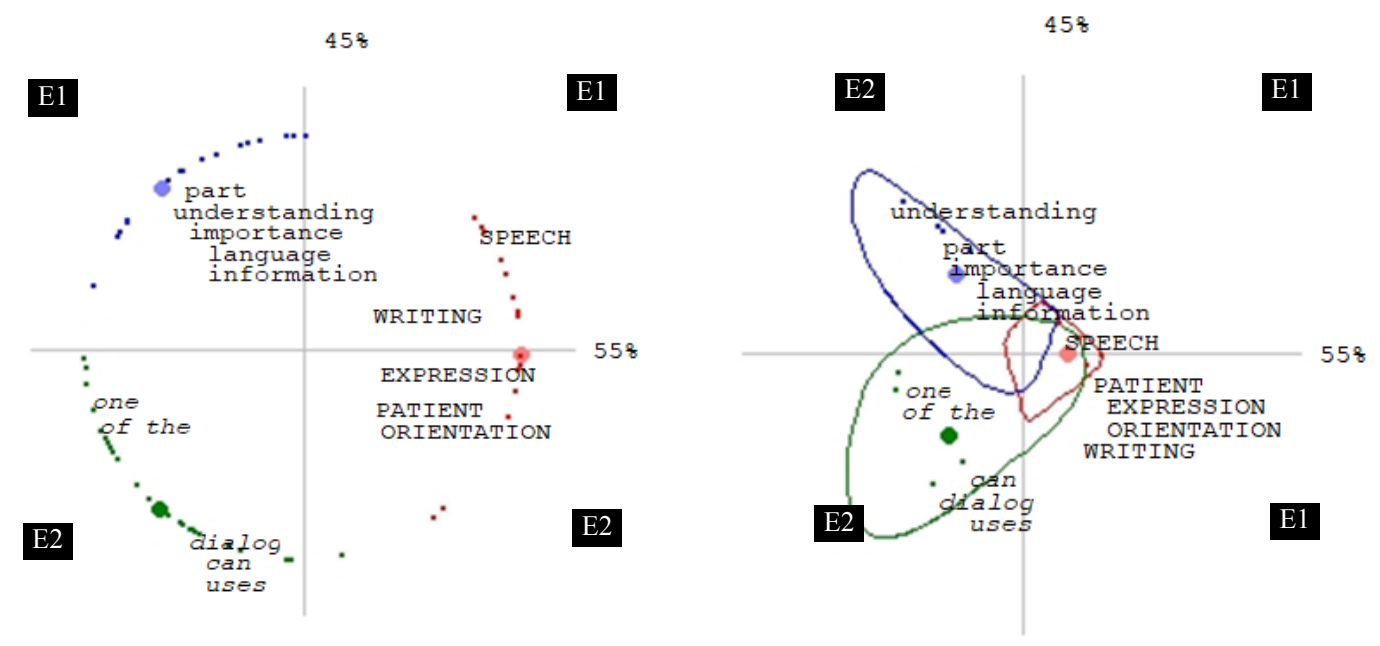

Figure 1 - Factorial analysis of correspondence and coordinates of three classes of pre-test of the expressions mentioned by the participants of the study, in uppercase (class 1), lower case (class 2) and italic (class 3)

Class 1 (uppercase) predominated in the corpus, with emphasis on the words "speech" $\left(X^{2}=25\right)$, "writing" ( $\left.\mathrm{X}^{2}=15\right)$, "expression" $\left(\mathrm{X}^{2}=8\right)$, "patient" $\left(X^{2}=23\right)$ and "orientation" $\left(X^{2}=8\right)$. Class 1 influenced the others, and there was a relationship between the reduced forms/words presented in the factorial analysis of correspondence.

Class 1, "Nurses' perception about verbal communication and its importance for nursing", was composed by $39 \mathrm{ECU}$ in this class that refer to the nurses' conceptions and knowledge about verbal communication. Verbal communication is spoken language; it is communication through speech between two people or a group of people. There is also the written language, which is communication through writing; or media, such as the Internet, the radio (ICU24).

ICU 10 demonstrated interest and ignorance with the theme "Communicating with the blind patient", reinforced by the absence of Braille mention in the speeches, which was restricted to the use of speech and writing.
Class 2, "Nurses' perception of non-verbal communication in nursing consultation", was constituted by $12 \mathrm{ECU}$, or $19.0 \%$ of the total corpus analyzed. In CFA, class 2 (lower case) presented, with prominence, the forms and frequencies of chi-square: "part" $\left(X^{2}=9\right)$, "understanding" $\left(X^{2}=5\right)$, "language" $(X 2=6)$ and "information" ( $\left.\mathrm{X}^{2}=7\right)$. The forms of non-verbal communication pointed out in the testimonials of this class were: gestures, Libras, touch, body and facial expressions. In ICU07, we observe erroneous concepts about non-verbal communication. One of the forms of non-verbal communication is the language from the body. Facial expression, touch, gestures, or... (concept error, our emphasis) ... from writing, from something to be read or something to be seen, on banners, billboards. Braille is another form of non-verbal communication (UCI07).

Class 3 of the pre-test, in italics in the CFA in Figure 1, shows the reduced forms and words of higher frequency in the corpus: "a" $\left(X^{2}=16\right)$, "of" $\left(X^{2}=8\right)$, "dialogue" ( $\left.X^{2}=9\right)$, "I can" $\left(X^{2} k^{2} i^{2}=4\right)$ and "uses" $\left(X^{2}=8\right)$. This class was called "Communication in the nursing 
consultation with blind person", composed of 10 ECU, which represented $17.0 \%$ of the analyzed material. The use of objects with blind people is important to remove barriers or explain the use of objects used in the consultation (ICU03). Libras is a form of communication in which tact is the main instrument for its execution... (concept error, our emphasis) ... it is used for communication with hearing impaired people (ICU05).

In the testimonies of ICU03, we emphasized space organization in the consultation with blind people. However, in ICU05, the informant described Libras incorrectly, as a language developed using tact and not gesture. The description of the communication focused on people with disabilities and their use in nursing care were superficial before the course.

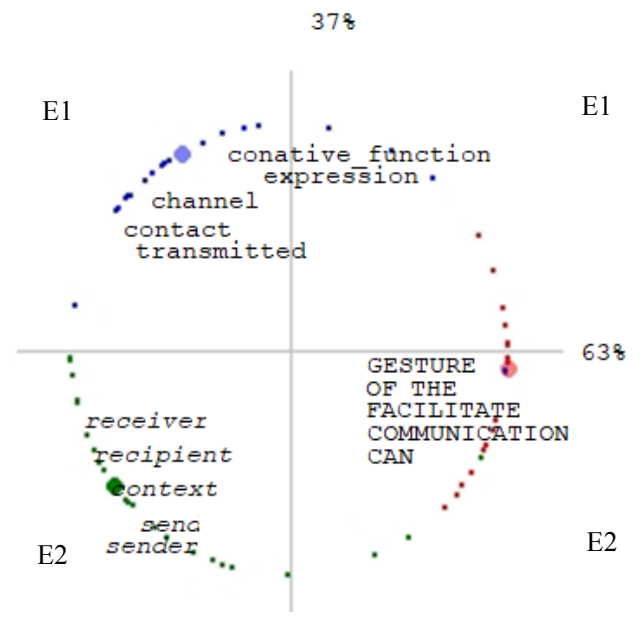

The results showed limited knowledge of the nurses on the subject before the application of the educational e-learning program, who did not differentiate the forms of verbal and non-verbal communication in the approach with the blind patient.

\section{Knowledge of nurses on communication with blind patients after e-learning course}

Figure 2 shows the CFA in different colors, according to the semantic relationship. The highlighted words were the most relevant in the Chi-squared test. The CFA evidenced greater interaction and semantic relationship between the reduced forms/words in the classes generated from the post-test.

378

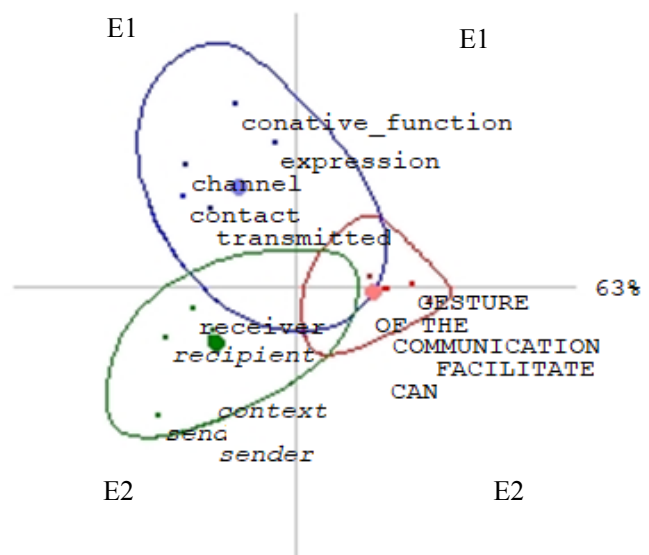

Figure 2 - Factorial analysis of correspondence of the post-test three classes. Upper case: class1; lower case: class 2; italic: class 3

In class 1 (upper case) appears as predominant forms and respective frequencies "gesture" $\left(X^{2}=15\right)$, "communication" ( $\left.X^{2}=14\right)$, "facilitates" $\left(X^{2}=6\right)$ and "can" $\left(X^{2}=11\right)$, with strong influence on class 3 (italic).

The most frequent forms and words in class 2 (lower case) were: "conactive function" $\left(X^{2}=6\right)$, "expression" $\left(X^{2}=6\right)$, "channel" $\left(X^{2}=7\right)$, "contact" $\left(X^{2}=8\right)$, "transmitted" $\left(X^{2}=9\right)$. In class 3 (italic) the shapes highlighted were "sender" $\left(X^{2}=13\right)$, "recipient" $\left(X^{2}=12\right)$, "receiver" $\left(X^{2}=10\right)$, "contexto" $\left(X^{2}=12\right)$ and "send" $\left(X^{2}=4\right)$.
Class 1, "Non-verbal communication in nursing care to the blind patient", covered $32 \mathrm{ECU}$, which represent $56.0 \%$ of the post-test corpus analysis. Non-verbal communication represents various types of communication, such as speech, writing, gestures, which facilitate communication with the blind patient... paralanguage is a form of non-verbal communication that considers characteristics of the vocal expression, the voice can reveal emotional state, age, gender, geographical origin. Proxemics theory studies the form of communication that considers interpersonal distance (ICU04).

The speech of the ECU04 expressed confusion between the forms of verbal and non-verbal com- 
munication, when considering speech and writing as non-verbal. Still, the content revealed the acquisition of knowledge about proxemics theories and paralanguage by means of e learning.

Class 2, "Elements and functions of verbal communication in the blind patient consultation", was composed of $10 \mathrm{ECU}$, or $17.0 \%$ of the post-test corpus analyzed. In this class: Communication elements are the message, the sender, the recipient, the context, the contact, and the channel. The functions of verbal communication are: reference function or informative function, expressive function or expression of feelings, spoken directly to the receiver and conactive function used in the imperative (ICU10).

Class 3, "Forms of verbal communication in the blind patient consultation", composed of 16 ECU, represented $27.0 \%$ of the corpus. It has the smallest contribution of ECU volume of the post-test. Braille is a written language used by the blind person and of great importance for their social inclusion (ICU01). The forms of verbal communication are speech, where through words we form a message to convey to the recipient, writing and Braille, which is an alphabet used by people with no visual acuity or low vision to transmit or have access to a message (ICU03).

We perceive, in the testimony of ICU01, awareness of the importance of communication for social inclusion of visually impaired people, with emphasis on the use of Braille, pointed out as a form of verbal communication, which was described as the alphabet used by blind patients.

It was feasible to communicate verbally with the blind patient even if they do not know Braille, because oral verbal communication fulfilled this function, which should be reinforced by the non-verbal, through touch. After the course, Nurses started to consider Braille a possibility of verbal communication in the consultation with the blind patient. The classes generated by the software ALCESTE in the post-test evidence that the nurse acquired the elements and functions of oral and written verbal communication, and described theories of non-verbal communication, relating their uses in the consultation with the blind patient.

\section{Discussion}

The limits of the study relate to the methodological choice of analysing the acquisition of knowledge through the application of pre and post-test instruments, because such a strategy can have a positive influence in the process, by offering training on thematic of difficult opportunity within the health services. The results of this study contributed significantly to the large-scale training of primary care nurses by means of validated e-learning educational strategy.

In the implementation phase, the educational program presented low adhesion and high evasion of nurses. Although the accessibility of the disabled person is a priority topic, it is not disclosed in the field of health. In the region of application of the study, despite widespread disclosure, few professionals were interested in the theme. In Brazil, the rates of e-learning programs evasion reach $48.0 \%$ of the s subscribers ${ }^{(9)}$. This study surpassed the average value for the country. "Evasion" means the decline in the number of students from the beginning to the end of the course, program or system. External factors may be the prioritization of other activities, the lack of ability to study in an e-learning modality, health problems and the non-adaptation to the virtual learning environment.

The current training of professionals must necessarily incorporate the new of communication and teaching-learning modes. Therefore, digital inclusion is essential for qualification and to keep nurses in the job market ${ }^{(10)}$. To evaluate the educational e-learning program, within the framework of the Unified Health System, we used, as a comparison parameter, the knowledge of nurses on communication with the blind patient before and after the course. The competence of communication is a skill that must be developed by health professionals and can be expanded in undergraduate and specialization programs, as well as continuing education programs ${ }^{(11)}$.

In the pre-test, the speeches of the nurses pointed out the verbal communication as the most used in the interaction with blind patients, expressed 
only by oral speech and writing. It was evident that Braille, written verbal language used by blind people, was not the channel of verbal communication in the daily assistance to this public. This is because health professional does not know it and there is a lack of educational material written and in Braille, in assistance practice, as a communication tool that could be accessed by people with disabilities in the context of primary care.

Commonly, in health services, the most widely used communication channels are the visual ones, which limits of blind people to the access and incorporation of meaningful information. Tact involvement is necessary as a communication channel relevant to the performance of certain activities by visually impaired people ${ }^{(12)}$. In the channels of verbal communication, considered by the nurses in the pre-test, they most frequent were written language such as letters, newspaper, books and Internet; Also, erroneously, billboards and posters were quoted as non-verbal channels of communication.

The educational program implemented promoted knowledge on the six elements of verbal communication, namely: sender, message, recipient, context, code and contact. However, this knowledge are limited to the conceptual level. These elements can make communication more effective, and its proper use allows the nurse to perceive the implicit or explicit messages of the patients ${ }^{(13)}$.

In relation to the functions of verbal communication of the subjects' speeches, only the conactive, expressive and referential were mentioned, but without describing them. This highlights the need to deepen this content with the nurses and report their application in the nursing consultation with the blind patient. These functions require the presence of the six elements in the communication process ${ }^{(14)}$.

The functions and elements of communication, being subjects of great specificity and depth, represent a challenge in e-learning, because they demand time and praxis to acquisition. In nurses' speeches, there are no elements that discuss aspects of the space between interlocutors and environmental conditions ${ }^{(14)}$.

Besides the gestures, facial expressions, voice timbre, touch and body distance should be considered in non-verbal communication, as well as the description of the environment, among other components that must be aligned to the preparation of the consultation space ${ }^{(15)}$.

Research shows that $55.0 \%$ of the feelings are expressed by non-verbal communication, $38.0 \%$ by voice and only $7.0 \%$ are represented by words ${ }^{(16)}$. Therefore, non-verbal communication allows perceiving and understanding, not only the words, but the feelings of the interlocutor ${ }^{(17)}$. When communicating with blind patients, the nurse must pay attention to these aspects. Before the e-learning course, the group did not know or did not refer to the dimensions of non-verbal communication. In the post-test, they approached these elements and characteristics. They also contemplated the proxemia, describing it as the inseparable relationship between the interlocutors positioning and the disposition of the furniture, for properly receiveing the blind patient in the office. They also highlighted that external movements and noises may favor or impair communication with the blind patient.

The dimensions of non-verbal communication were acquired in the educational program. Subjective aspects, expressed in proxemic forms (positioning of people in interaction), tactic (Touch Care), kinesic (movements) and by paralanguage (sound that does not translate into words), should broaden the skills of health professionals, to perceive and translate non-verbal communication ${ }^{(18)}$. The course ensured competence for nurses, in acquiring knowledge about the elements, forms, functions and the importance of communication to nursing. However, information from this universe should be deepened, as we identified group's difficulties such as to the use of these elements in the nursing consultation with the blind patient. Convinced of the importance of communication 
for accessibility in the Unified Health System, the participants of the study suggested more courses about this thematic, with practical examples for application in primary care.

\section{Conclusion}

The educational program allowed the nurses' acquisition of knowledge for verbal and non-verbal communication with the blind patient in nursing consultation in primary health care.

\section{Acknowledgements}

Multicentric study funded by the Ceará Fundação Cearense de Apoio ao Desenvolvimento Científico e Tecnológico, a member of the Research Program for the Unified Health System, in partnership with the Universidade Federal do Ceará, the Universidade Regional do Cariri and Universidade da Integração Internacional da Lusofonia Afro-Brasileira. Process number 13694042-0.

\section{Collaborations}

Soares JR, Pagliuca LMF, Barbosa EMG and Maia ER contributed to the design of the analysis and interpretation of the data; Writing the article or relevant critical review of the intellectual content and final approval of the version to be published.

\section{References}

1. Krahn GL, Walker DK, Correa-De-Araujo R. Persons with disabilities as an unrecognized health disparity population. Am J Public Health. 2015; 105(Suppl2):198-206. doi: http://dx.doi. org/10.2105/AJPH.2014.302182

2. Martins KP, Costa KNFM, Rezende LCM, Gomes TM, Dantas TRA, Santos SR. Perception of nursing staff about physical accessibility and communication of people with visual impairment. Ciênc Cuid Saúde. 2015; 14(2):1019-26. doi: http://dx.doi. org/10.4025/cienccuidsaude.v14i2.22045
3. Cintra AP, Souza LP. Pessoas com deficiência severa na Região Sul do Brasil: características da população segundo os Censos 2000 e 2010. Cad IPARDES [Internet]. 2012 [citado 2018 abr. 11]; 2(2):68-86. Disponível em: http://www.ipardes. pr.gov.br/ojs/index.php/cadernoipardes/article/ view $/ 535 / 725$

4. Mathos KK, Pollard RQ. Capitalizing on community resources to build specialized behavioral health services together with persons who are deaf, deafblind or hard of hearing. Community Ment Health J. 2016; 52(2):187-93. doi: https://doi. org/10.1007/s10597015-9940-y

5. Wylie L, McAllister BD, Marshall J. Changing practice: Implications of the world report on disability for responding to communication disability in under-served populations. Int J Speech Lang Pathol. 2013; 20(1):1-13 doi: https://doi.org/10.3109/1 7549507.2012.745164

6. Shamshiri M, Mohammadi N, Cheraghi, MA, Vehviläinen-Julkunen $\mathrm{K}$, Sadeghi T. Disciplined care for disciplined patients: experience of hospitalized blind patients. Holist Nurs Pract. 2013; 27(6):344-8. doi: http://dx.doi.org/10.1097/ HNP.0b013e3182a72bcd

7. Hartley MD, Ludlow BL, Duff MC. Second Life $\AA$ : A 3D virtual immersive environment for teacher preparation courses in a distance education program. Rural Spec Educ Quart. 2017; 34(3):21-5. doi: https://doi. org/10.1177/875687051503400305

8. Frye AW, Hemmer PA. Program evaluation models and related theories: AMEE Guide $\mathrm{n}^{\circ}$ 67. Med Teach. 2012; 34(5):e288-99. doi: http://dx.doi.or g/10.3109/0142159X.2012.668637

9. Castro e Lima Baesse D, Grisolia AM, Oliveira AEF. Pedagogical monitoring as a tool to reduce dropout in distance learning in family health. BMC Med Educ. 2016; 16(1):213. doi: http://dx.doi. org/10.1186/s12909-016-0735-9

10. Frota NM, Barros LM, Araújo TM, Caldini LN, Nascimento JC, Caetano JA. Construction of an educational technology for teaching about nursing on peripheral venipuncture. Rev Gaúcha Enferm. 2013; 34(2):29-36. doi: http://dx.doi. org/10.1590/S1983-14472013000200004 
11. Oliveira KR, Braga EM. The development of communication skills and the teacher's performance in the nursing student's perspective. Rev Esc Enferm USP. 2016; 50(n.spe):32-8. doi: http://dx. doi.org/10.1590/S0080-623420160000300005

12. Barbosa GO, Wanderley LD, Rebouças CB, Oliveira PM, Pagliuca LMF. Development of assistive technology for the visually impaired: use of the male condom. Rev Esc Enferm USP. 2013; 47(5):1158-64. doi: http://dx.doi.org/10.1590/ S0080-623420130000500021

13. Melo GM, Rebouças CBA, Cardoso MVML, Farias LM. Comunicação de profissionais de enfermagem ante a dor de neonatos: estudo descritivo. Online Braz J Nurs [Internet]. 2013 [citado 2018 abr. 11]; 12(3):462-70. Disponível em: https://www. objnursing.uff.br/index.php/nursing/article/ viewFile/4019/2195

14. Lima MB, Silva CCF, Pagliuca LMF, Rebouças CBA. Educação a distância para comunicação entre enfermeiros e cegos. J Health Inform [Internet]. 2012 [citado 2018 Apr 11]; 4:226-9. http://www. jhi-sbis.saude.ws/ojs-jhi/index.php/jhi-sbis/ article/view/213/154
15. Rebouças CBA, Pagliuca LMF, Sawada NO, Almeida PC. Validation of a non-verbal communication protocol for nursing consultations with blind people. Rev Rene [Internet]. 2012 [cited 2018 Apr 11]; 13(1):125-39. Available from: http://www. revistarene.ufc.br/revista/index.php/revista/ article/view/24

16. Broca PV, Ferreira MA. Equipe de enfermagem e comunicação: contribuições para o cuidado de enfermagem. Rev Bras Enferm. 2012; 65(1):97103. doi: http://dx.doi.org/10.1590/S003471672012000100014

17. Ramos AP, Bortagarai FM. A comunicação nãoverbal na área da saúde. Rev CEFAC. 2012; 14(1):164-70. doi: http://dx.doi.org/10.1590/ S1516-18462011005000067

18. Bax AM, Araujo ST. No verbal expression from the patient in care: perception of the nurse in cardio intensive care unit. Esc Anna Nery. 2012; 16(4):728-33. doi: http://dx.doi.org/10.1590/ S1414-81452012000400012 